\title{
ADDENDUM
}

\section{NATO's strategic narratives: Angelina Jolie and the alliance's celebrity and visual turn - ADDENDUM}

\author{
Katharine A. M. Wright ${ }^{1 \star}$ (D) and Annika Bergman Rosamond ${ }^{2}$ \\ ${ }^{1}$ School of Geography, Politics and Sociology, Newcastle University, Newcastle, United Kingdom and ${ }^{2}$ Department of \\ Political Science, Lund University, Sweden \\ ${ }^{*}$ Corresponding author. Email: Katharine.a.m.wright@newcastle.ac.uk
}

(First published online 31 May 2021)

https://doi.org/10.1017/S0260210521000188, Published by Cambridge University Press, 10 May 2021.

The above article was published with a sentence missing from the Acknowledgements. The article has been updated to reflect this.

The authors apologise for this error.

\section{Reference}

Wright, K. A. M., Bergman Rosamond, A. 2021. NATO's strategic narratives: Angelina Jolie and the alliance's celebrity and visual turn. Review of International Studies X: 1-24. https://doi.org/10.1017/S0260210521000188

Cite this article: Wright, K. A. M., Bergman Rosamond, A. 2021. NATO's strategic narratives: Angelina Jolie and the alliance's celebrity and visual turn - ADDENDUM. Review of International Studies 47, 467-467. https://doi.org/10.1017/ S0260210521000310

(C) The Author(s), 2021. Published by Cambridge University Press on behalf of the British International Studies Association. This is an Open Access article, distributed under the terms of the Creative Commons Attribution-NonCommercial-NoDerivatives licence (http://creativecommons.org/licenses/by-nc-nd/4.0/), which permits non-commercial re-use, distribution, and reproduction in any medium, provided the original work is unaltered and is properly cited. The written permission of Cambridge University Press must be obtained for commercial re-use or in order to create a derivative work. 